\title{
COMBINATION OF POWER AND KWL STRATEGIES TO TEACH WRITING
}

\author{
Ichsanira Purwandari ${ }^{1}$; Sri Wiyanah² \\ ${ }^{1} \underline{\text { Ichsanira5595@gmail.com }}$ \\ ${ }^{1}$ University of PGRI Yogyakarta \\ 2wiyana.pbiupy@gmail.com \\ ${ }^{2}$ University of PGRI Yogyakarta
}

\begin{abstract}
The aim of the study was to identify the effectiveness of using the combination of POWER and KWL to teach writing of fourth semester students at English Language Education Study Program in the University of PGRI Yogyakarta. It is based on the research problem that the students got difficulties on writing because they used ineffective strategy. The research used experimental research design. This research was conducted in 3 stages: data collection, action and data analysis. The data were collected through test, observation, and questionnaire. The data were analyzed using the steps of: normality test, homogeneity test, inferential analysis, determining hypothesis testing, and conclusion.The hypothesis is determined into the Null hypothesis ( $\mathrm{H} 0)$ and Alternative Hypothesis (Ha). $\mathrm{HO}$ is accepted if the significance value $>0.05$ and $\mathrm{Ha}$ is rejected. The result of this research presented that the combination of POWER and KWL strategy was effective to teach writing at the university level. The control group's mean score on the pre-test was 56,22 increased to 57,88 in post-test with gained point 1,59 . The experiment group's mean score on pre-test was 57,33 increased to 60,89 on post-test with gained point 3,66 .
\end{abstract}

Keywords: Experimental Research, POWER strategy, KWL Strategy, teaching writing

\section{INTRODUCTION}

Writing is a complex activity that cannot be mastered instantly, it needs certain processes. According to Hedge (2000:308), writing is an active skill as in the act of creating a text, we required to do several steps such as setting goals, generating ideas, organizing information, selecting the appropriate language, making a draft, reading and reviewing, then revising and editing. Therefore, students must have a lot of practice to write good content. 
Students must have an appropriate strategy to improve their writing skills. Especially for English Language Education students, they must have an excellent writing skill due to their obligation to pass the IELTS test, write a certain paper, and undergraduate thesis. The observation was conducted in the writing class of English Language Education Department of the University of PGRI Yogyakarta. Students face some problems related to writing skill. The problems related to vocabulary, language feature, text organization, and the failure in expressing their ideas.

One of the problems which lead the researcher to conduct this research is when students write, they failed to develop their paragraph because they did not know how to continue their writing. They usually have an ineffective approach in the writing process and lack of writing knowledge. That was not caused by their lack of creativity, but they lack writing strategy. That problem appeared because of monotonous learning, students were not active to gain the idea, they did not make any draft before they started to write the passage, or students did not have any idea to develop their writing. The research problem i.e, How is the effectiveness of using a combination of POWER and KWL strategies to teach writing for the fourth-semester students of English Language Education Study Program at the University of PGRI Yogyakarta? Nunan (2008: 31) stated that writing is the process of thinking to find ideas, how to express the idea into great writing, and arranged them into proper statements and paragraphs.Writing cannot be done perfectly without errors during the process. Second language writing must then be taught continuously and patiently for a long period. There is no definite time whether teaching writing will stop after a few days, months or must be continued in the next few years. Therefore, it is considered as a writing process. Teaching writing requires repeatedly practices to get results According to Harmer (2007: 330), there are three roles of English teachers in teaching writing i.e. motivator, resource and feedback provider. In addition, the teacher must have a strategy to make learning effective and interactive. Harmer (2004: 11) states that the students should pay attention to what to write and how to write. Writing is the process of generating the idea to become a meaningful sentence or paragraph. There are several strategies to make good writing. The strategy also be the priority in the teaching process as the engagement for students and teacher. Therefore, strategy 
in the teaching-learning process considers important components to attain meaningful and effective teaching.

Hassard (2011: 77) states KWL is a strategy that allows students to make a prediction about what they will read or write. The column in the chart namely "K (what I know)", "W (what I want to know)", and "L (what I learned)". The KWL strategy helps the students to write under the framework of writing a purpose and the applied of writing elements based on their background knowledge and experience towards the topic. Bloom in Hurd (2008:109) mentioned the procedure of using the KWL Technique. In the "Kee column, students independently write down information that they already know toward their writing topic. In the " $\mathrm{W}^{\mathrm{ee}}$ column, learners write down the questions to elaborates their background knowledge about what they still need to gain about the writing topic. This step guides their elaboration process by producing clear objectives. Then, in the " $\mathrm{L}^{\text {ce }}$ column, students write down what they learned from their writing. It related to the topic, grammatical features, and text organization.

According to Fearn and Fernan in Frey (2011:142), the POWER writing strategy is a method to improve the fluency on writing through a brief time writing event. The POWER technique five steps of the writing process: Planning, Organizing, Writing, Editing, and Revising (Englert, Raphael, Anderson, Anthony, Fear, \& Gregg, 1988). Those steps are explained below:

\section{a. Planning}

At this step, students decide the purpose of the text, and who is the reader.

b. Organizing

Students organize the idea according to the text structure. They may also follow the certain writing template, according to the text type.

c. Writing

Students make the first draft on this stage based on the result of previous stages.

\section{d. Editing}

Students evaluate their writing, then they may continue with peer editing with their sit mate. At this stage, students will be given certain guidelines to evaluate.

e. Revising 
This is the last step of writing, students need to rewrite their text according to the previous stage result, and do some improvements.

The benefits of POWER writing strategy i.e., straightforward, easy to explain and understand, increase students' motivation, help student to write quickly, encourage activity, build confidence and the students can produce their writing easily

Considering the advantages of those strategies, it will be effective to improve students' writing achievement. The writer combines the procedures of those two strategies as follows:

a. Planning

1) Lecturer gives students a bar diagram and the data

2) Students are asked to collect information from the bar diagram and write it down on the K column of the KWL table

b. Organizing

1) Lecturer asks students to organize the mind idea for each paragraph

2) Students are asked to arrange their information that has been written down on paper in planning stages according to their main ideas.

c. Writing

Lecturer asks students to make a draft

d. Editing

1) Students are asked to evaluate their draft

2) Students may give their text to the lecturer or another student for words and grammar correcting

3) The lecturers and the corrector may suggest the correct writing

4) Lecturer asks the students to give the text back to the owner

e. Revising

1) Student are asked to write their correct form of the text in another paper

2) Student are asked to submit their work

Dwi Siswoyo (2007: 121) stated that students at the university level are individuals with high intelligence, critical thinking, and quick in action. Therefore, students at the university level should be treated properly in learning. Specifically, in writing class, university level students have the potency to produce excellent writing. Their 
experience and background knowledge can support them to achieve a higher writing score.

The explanations above encourage the writer to use the combination of those two strategies to teach writing in the classroom. Through this combination of strategies, students will be more enthusiast in learning because they can produce text easier. Therefore, the goals of writing itself will be achieved. The writer uses the combination of POWER and KWL strategy to teach writing for the fourth-semester class of English Language Education Study Program at the University of PGRI Yogyakarta as the following stages:

a. The lecturer asks the students to prepare three sheets of papers

b. The lecturers prepare some topics or data.

c. Students are asked to write the information that they have been collected in the K column of the KWL table.

d. Then, students are asked to write the elaboration of the ideas in the $\mathrm{W}$ column of the KWL table.

e. The students arrange the elaboration of their idea in the good paragraph form.

f. Students are asked to check their writing. It involves their grammar, vocabulary, language feature, punctuation, capitalization, and sentence organization.

g. Students evaluate their writing then write down their mistake in L column of KW-L table.

h. Students revise their writing with the correct form.

Using a combination of POWER (Planning-Organizing- Writing-Editing-Revising) and KWL (Know-Want to learn-Learned) will be effective to teach writing for the fourth-semester class of English Language Education Study Program in the University of PGRI Yogyakarta.

H0: There is no significant difference in students' writing achievement between students who taught by using mind mapping and the combination of KWL and POWER strategies.

Ha: There is a significant difference in students' writing achievement between students who taught by using mind mapping and the combination of KWL and POWER strategies. 
The assumption of those hypotheses as follows:

If $\mathrm{HO}$ is rejected, it means that there is a significant difference between the students' writing ability before and after being taught by using the combination of POWER and KWL strategy. So vice versa, if $\mathrm{H} 0$ is accepted means that there is no significant difference between the students' writing ability before and after being taught by using those strategies.

\section{RESEARCH METHOD}

The research design is experimental. As what Sugiyono (2016:72) states that experimental research is a research which has the purpose to find the cause-effect relationship among variables in a controlled condition. This research implemented a preexperiment method with pre-test and post-test design. To identify whether there is any significant influence towards the use of a combination of POWER and KWL strategies for students' writing skills, the writer used the comparative technique to analyze and compare the students' scores before and after being taught by using those strategies. This research was conducted at the fourth-semester class of English Language Education Study Program in the University of PGRI Yogyakarta. The university is located in PGRI II Street, Bantul, Yogyakarta.

The population used in this research are the students of the English Language Education Department at the University of PGRI Yogyakarta. Students in that department can write text in English. The students consist of second until eighth semesters, which each grade consists of a class. This research used the fourth-semester students of English Language Education Study Program at the University of PGRI Yogyakarta as the sample. That class consists of 18 students. The sampling technique used was simple random sampling because the sample contains subjects with similar characteristics to the whole population (Cohen, Manion, \& Morrison, 2007:111). The population was separated into two groups; control group and experiment group, each group consists of 9 students.

Technique and Instrument in collecting data are test, obervation and questionaire. To find out the effectiveness pre-test and post-test were conducted to see the students' achievements. Pre-test aimed to determine students' basic condition to produce a text, meanwhile post-test aimed to determine students' writing ability after getting the 
treatment. Pre-test was conducted for the students in written test form. Students were asked to write their idea based on the bar diagram given by the writer. Then, the writer evaluates the result by using the specific scoring rubric. Meanwhile, post-test, the writer gave the post-test after the treatment had been done by teaching writing using the combination of POWER and KWL strategies.

Observation focuses on the events that happened in the classroom. It includes the number of students, students' condition, and their behavior during the teaching-learning process (Cohen, Manion, \& Morrison, 2007:396)Observation sheets were attached in this research to check the steps of the teaching-learning process. It consists of teaching and learning activities details that should be done both by teacher and students. In addition, the instrumen of observation used observation sheets. The questionnaire that used in this research was close-ended questionnaire. A close-ended questionnaire is a form of questionnaire which expected to be answered by choosing the available answer (Sugiyono, 2015:201). Questionnaire aimed to support the main data of the research from the result of pre-test and post-test.

According to Arikunto (2006: 158), a valid instrument qualification is measurable therefore it can reveal the data of the variables appropriately. In this study, the instrument used is a writing test. Validity is used to measure that the instruments are adequate to be used in the research. The instruments were constructed based on the material taught in the academic writing class. Sugiyono (2015: 173) states that valid means the instrument is able to measure what supposed to be measured. All of the research instruments have been validated by the research supervisor. Cohen et al (2007:146) state that reliability in quantitative research is essentially related to consistency and dependability over instruments and respondent groups.

\section{RESULTS AND ANALYSIS}

This research was conducted in May-June 2019. The sample of this research was 18 students of fourth-semester class of English Language Education Study Program of the University of PGRI Yogyakarta. The students were divided into two groups: control and experiment. Control and experiment groups were treated in a completely different way. The control class was taught by using mind mapping writing strategy, while the experiment class was taught by using the combination of POWER and KWL strategy. 
In collecting the data, students in the control group were taught by using mind mapping as the conventional method, meanwhile, the experiment group was taught by using the combination of POWER and KWL strategy. The following table shows the student's result on pre-test and post-test, which represents the effectiveness of using a combination of POWER and KWL strategy in teaching writing.

Table 3. 1 Test Score of Experiment Group

\begin{tabular}{|l|l|l|l|}
\hline No & \multicolumn{2}{|l|}{ Experiment Group } & $\begin{array}{l}\text { Gain } \\
\text { Score }\end{array}$ \\
\hline & Pre Test & $\begin{array}{l}\text { Post } \\
\text { Test }\end{array}$ & \\
\hline 1 & 58 & 62 & 4 \\
\hline 2 & 56 & 59 & 3 \\
\hline 3 & 61 & 65 & 4 \\
\hline 4 & 54 & 58 & 4 \\
\hline 5 & 57 & 60 & 3 \\
\hline 6 & 62 & 65 & 3 \\
\hline 7 & 53 & 57 & 4 \\
\hline 8 & 60 & 63 & 3 \\
\hline 9 & 55 & 59 & 4 \\
\hline Mean & 57,33333 & 60,88889 & \multicolumn{2}{|l|}{} \\
\cline { 1 - 3 } & & \multicolumn{2}{|l|}{} \\
\cline { 1 - 3 } & & &
\end{tabular}

Table 3.1 reveals that the lowest score of pre-test in the experiment class is 53 and the highest score is 62. The mean of the pre-test in the experiment class is 57. Meanwhile, the lowest score of the post-test in the experiment class is 57 and the highest score is 65 . The mean of the post-test in the experiment class is 61 . Therefore, it can be summarized that the combination of POWER and KWL strategy is effective in teaching writing at the university level because the mean scores of the post-test are higher than the pre-test.

Table 3. 2 Test Score of Control Group

\begin{tabular}{|l|l|l|l|}
\hline No & \multicolumn{2}{|l|}{ Control Group } & Gain Score \\
\hline & Pre Test & Post Test & \\
\hline 1 & 60 & 62 & 2 \\
\hline 2 & 57 & 58 & 1 \\
\hline 3 & 54 & 56 & 2 \\
\hline 4 & 59 & 60 & 1 \\
\hline
\end{tabular}




\begin{tabular}{|l|l|l|l|}
5 & 60 & 63 & 3 \\
\hline 6 & 52 & 53 & 1 \\
\hline 7 & 54 & 56 & 2 \\
\hline 8 & 58 & 60 & 2 \\
\hline 9 & 52 & 53 & 1 \\
\cline { 1 - 3 } MEAN & 56,22222 & 57,88889 & \multicolumn{1}{|l|}{} \\
\cline { 1 - 2 }
\end{tabular}

Table 3.2 describes that the lowest score of pre-test in the control class is 52 and the highest score is 60 . The mean of pre-test in the control class is 56. Meanwhile, the lowest score of the post-test in the control class is 53 and the highest score is 63 . The mean of the post-test in the experiment class is 58. Therefore, it can be summarized that the mind mapping method is less effective because the score obtained by students does not increase significantly as writing using the combination of POWER and KWL strategy.

The pre-test activity is conducted before the treatment process. Both of control and experiment groups were included in this test. This test aimed at knowing the basic condition before the subjects were given the treatment, also measured their earlier knowledge. The pre-test activity was attended by all of the research subjects. There were 18 students of the fourth-semester of English Language Education Study Program of the University of PGRI Yogyakarta. The time allocated for conducting this activity was 50 minutes. On the pre-test activity, students were given a writing task. They were asked to write a passage within 150 words based on the bar graph that has been given. Their passages were assessed by using the specific scoring rubric, then the result was analyzed by using SPSS 16 . The result can be seen in the following table:

Table 3. 3 Comparison of Control and Experiment Groups Pre-test Result

\begin{tabular}{|l|l|l|l|l|}
\hline & \multicolumn{1}{|c|}{ N } & \multicolumn{1}{|c|}{ Minimum } & Maximum & Mean \\
\hline Pre-Test Experiment & 9 & 53 & 62 & 57,33 \\
Pre-Test Control & 9 & 52 & 60 & 56,22 \\
Valid N & 9 & & & \\
\hline
\end{tabular}

The table above is the descriptive statistics of the control and experiment group pre-test results. It can be seen that the lowest score of the control group is 52, and the highest is 60 , then the mean is 56. Meanwhile, the lowest score in the experiment group is 53, and the highest score is 62 , then the mean is 57 . To make the data can be interpreted easier, the writer made the distribution table of the students' pre-test score. It can be seen as follows: 


\section{Post-test}

The post-test activity was conducted after the treatment has been done. Both of control and experiment groups were involved in this activity. The post-test activity aimed to measure the students' achievements after the treatment was given. The result of students' post-test are shown in the following table:

Table 3.4 Control and Experiment Group Post-test Score

\begin{tabular}{|c|c|c|c|}
\hline \multicolumn{2}{|c|}{ Control Group } & \multicolumn{2}{c|}{ Experiment Group } \\
\hline Respondent Number & Score & Respondent Number & Score \\
\hline R1 & 62 & R1 & 62 \\
\hline R2 & 58 & R2 & 59 \\
\hline R3 & 56 & R3 & 65 \\
\hline R4 & 60 & R4 & 58 \\
\hline R5 & 63 & R5 & 60 \\
\hline R6 & 53 & R6 & 65 \\
\hline R7 & 56 & R7 & 57 \\
\hline R8 & 60 & R8 & 63 \\
\hline R9 & 53 & R9 & 59 \\
\hline
\end{tabular}

The post-test activity was attended by all of the research subjects. There are 18 students of the fourth-semester of English Language Education Study Program of the University of PGRI Yogyakarta. The time allocated for conducting this activity was 60 minutes. On the post-test activity, students were given a writing task. They were asked to write a passage within 150 words based on the bar graph that has been given. Their passages were assessed by using the specific scoring rubric, then the result was analyzed by using SPSS 16 . The result comparison can be seen in the table below:

Table 3.5 Result Comparison of Control and Experiment Groups Post-test

\begin{tabular}{|l|l|l|l|l|}
\hline & \multicolumn{1}{|c|}{ N } & Minimum & Maximum & Mean \\
\hline Post-Test Experiment & 9 & 57 & 65 & 60,89 \\
Post-Test Control & 9 & 53 & 63 & 57,89 \\
Valid N & 9 & & & \\
\hline
\end{tabular}

The table above is the descriptive statistics of the control and experiment group post-test results. It can be seen that the lowest score of the control group is 53, and the highest is 63 , then the mean is 58. Meanwhile, the lowest score in the experiment group is 57, and the 
highest score is 65 , then the mean is 61 . To make the data can be interpreted easier, the writer made the distribution table of the students' post-test score. It can be seen as follows:

The instruments that used such as pre-test, post-test, lesson plan, and questionnaire. Pre-test and post-test questions in the form of writing tasks. Students were asked to write a text within 150 words based on the bar graph that have given before. All of the research instrument have been validated by the research supervisor. In the general validation results, the instruments of research are appropriate for conducting experimental research.

After all of the data assumed as normal and homogenous, then the next step is determining the hypothesis. It is aimed at finding the effectiveness of POWER and KWL strategy towards students' writing achievement. The hypothesis elaborated as follow:

a. $\mathrm{H} 0$ is accepted if the significance value $>0.05$ and $\mathrm{Ha}$ is rejected.

It means that the combination of POWER and KWL strategy is not effective in teaching writing for fourth-semester students of English Language EducationStudy Program at the University of PGRI Yogyakarta.

b. H0 is rejected if the significance value $<0.05$ and Ha is accepted.

It means that the combination of POWER and KWL strategy is effective in teaching writing to the fourth-semester students of English Language Education Study Program at the University of PGRI Yogyakarta. The hypothesis test is carried out by using SPSS 16 PairedSample T-Test. Based on an explanation about hypothesis testing on the previous chapter, it can be concluded that if the significance value $<0.05$, it means $\mathrm{H} 0$ is rejected and $\mathrm{Ha}$ accepted, if the significance value $>0.05$, it means $\mathrm{H} 0$ is accepted and Ha rejected.

This research aimed to identify the effectiveness of using the combination of POWER and KWL strategy in teaching writing for fourth-semester students at the University of PGRI Yogyakarta. The research focuses on students' achievement in writing academic text. According to the data analysis result, students' achievements are significantly improved after being treated by using those strategies. It can be seen on the mean score result below:

Table 4. 1 Comparison of Mean Score

\begin{tabular}{|l|c|c|c|}
\hline \multicolumn{1}{|c|}{ Group } & Test & Mean & Gained Point \\
\hline Control Group & Prr-Test & 56,22 & \multirow{2}{*}{1,59} \\
\cline { 2 - 3 } & Post-Test & 57,88 & 1,59 \\
\hline Ezperiment Grouop & Pre-Test & 57,33 & 3,66 \\
\hline
\end{tabular}

Based on the table above, it can be concluded that the combination of POWER and KWL strategy is effective in teaching writing since the gained point of the experiment group is 
higher than the control group. The gained point shows 1, 59 for the control group, and 3, 66 for the experiment group $(3,66>1,59)$. That statement is supported by the T-test result that shows the significance value is lower than alpha $(0,000<0,05)$, which means that $\mathrm{HO}$ is rejected and $\mathrm{Ha}$ is accepted.

The statement above also supported by the result of the observation sheet and questionnaire data analysis. The observation sheet percentage is $90 \%$, which can be categorized as very good. It can be concluded that the implementation of the combination of POWER and KWL was successfully accepted by the students in the writing class. Furthermore, the questionnaire analysis shows that the percentage of students' opinion towards the use of combination of POWER and KWL strategy mostly are "yes". In their opinion, those strategy can help them to achieve the better writing result. Therefore, it can be concluded that the combination of POWER and KWL strategy is effective to teach writing in the fourth-semester class of English Language Education Study Program in the University of PGRI Yogyakarta.

\section{CONCLUSION}

The combination of POWER and KWL strategy is an effective strategy to teach writing at the university level. That strategy can improve students' writing academic achievement.

Meanwhile, conventional media is less effective to teach writing in fourth-semester students of English Language Education Study Program at the University of PGRI Yogyakarta. As a result of the hypothesis measured from the post- test of the experiment class. The result shows the t-test significance value is 0.000 which is lower than 0.05 . It means that $\mathrm{Ha}$ is accepted and $\mathrm{H} 0$ is rejected. It can be concluded that there is a significant difference in students' writing achievement that treated by using a combination of POWER and KWL strategy and students then who do not get the treatment is accepted.

\section{REFERENCES}

Arikunto, Suharsimi. (2009). Dasar- Dasar Evaluasi Pendidikan. Jakarta:Bumi Aksara.

Arikunto, Suharsimi. 2009.Manajemen Penelitian. Jakarta: PT Rineka Cipta.

Cohen, Louis., Manion, Lawrence., \& Morrison, Keith. 2007. Research Method in Education 6th Edition. London: Routledge Falmer. 
Dwi Siswoyo. (2007). Ilmu Pendidikan. Yogyakarta: UNY Press.

Frey, Nancy., Fisher, Douglas. 2011. The Formative Assessment Action Plan. United States: ASDC Publications.

Harmer, J. (2004). How to Teach Writing. Edinburg: Pearson Education Ltd.

Harmer, J. (2007). The Practice of English Language Teaching. Edinburg: Pearson Education Ltd.

Hassard, J. (2011). Science as Inquiry 2nd Edition. Culver, United States of America: Good Year Books.

Hedge, Tricia. 2000. Teaching and Learning in the Language Classroom. Oxford: Oxford University Press.

Hurd, Stella and Lewis, Tim. 2008.Language Learning Strategies in Independent Setting. Toronto: Multilingual Matters.

Nunan, D. 2008. Practical English Language Teaching. United States. Mc.Graw Hill.

Sugiyono. 2016. Metode Penelitian Kuantitatif Kualitatif dan R\&D. Bandung: Alfabeta. 